\title{
A Glimpse of Violence Against Patients and Relatives in the Emergency Department
}

\author{
Acil Serviste Hasta ve Hasta Yakınlarına Karşı Şiddete Bir Bakış
}

Mustafa Katran', (D) Yonca Senem Akdeniz ${ }^{2}$, Afsin Ipekci $^{2}$, ID Ibrahim Ikizceli ${ }^{2}$

1- İstanbul Medeniyet Üniversitesi, Göztepe Eğitim ve Araştırma Hastanesi, Acil Tıp Anabilim Dal, İstanbul, Turkey. 2- İstanbul ÜniversitesiCerrahpaşa, Cerrahpaşa Tıp Fakültesi, Acil Tıp Anabilim Dalı, İstanbul, Turkey.

\begin{abstract}
Objectives: We aimed to get a general opinion about characteristics of the violence, claimed that shown by healthcare workers against patients or relatives who applied to Cerrahpasa Medical Faculty Emergency Department, possible causes and preventive measures, and to evaluate the perspective of patients and relatives on violence in this study.

Material and Method: The questionnaire form was administered to 250 patients or relatives who applied to Cerrahpaşa Medical Faculty Emergency Department and aged 18 years and older.

Results: $20.4 \%$ (n:51) of the participants had reported exposure to violence in the hospital at least once. It is stated that the most prevalent type of violence was verbal violence $(n: 46)$ and violence occurred mostly in emergency departments $(n: 22)$. The assailants were mostly male and nurse/midwife/health staff. Violence exposure time was between 8:00 and 16:00 in 19 cases, between 16:00 and 24:00 in 19 cases, and between 24:00 and 8:00 in 12 cases. The majority of participants stated that they do nothing about the violence. The patient intensity was accused as the main cause of violence. Reduction in the patient's crowd was mostly suggested as a solution to violence.

Conclusion: These results can help in developing proper policy and safety measures for creating a safer hospital environment. It is necessary to perform interventions, especially to get a reduction in patient intensity and to improve miscommunication.

ÖZET

Amaç: Bu çalıșmada Cerrahpaşa Tip Fakültesi acil servisine bașvuran hastalar veya yakınlarına sağllk çalışanları tarafindan uygulandığı iddia edilen şiddetin özellikleri, olası nedenleri ve önleyici tedbirler hakkında genel bir fikir elde edilmesini ve şiddete hasta veya yakınlarının bakış açısını değerlendirmeyi amaçladık.

Gereç ve Yöntem: Cerrahpașa Tip Fakültesi acil servisine bașvuran, 18 yaș ve üzeri, 250 hasta veya yakinlarina anket formu uygulandi.

Bulgular: Katılımcıların \%20.4'ü (n:51) hastanede en az 1 kez şiddete uğradı̆̆ını belirtti. En çok karşılaşılan şiddet tipinin sözel şiddet (n:46) olduğu ve şiddetin en slk acil servislerde gerçekleştiği (n:22) belirtildi. Saldırganların çoğu erkek ve hemşirelebe/sağllk memuru idi. Şiddete maruziyet zamanı 19 olguda saat 8-16 arası, 19 olguda saat 16-24 arast ve 12 olguda saat 24-8 arası idi. Katılımcıların çoğu şiddetle ilgili hiç bir şey yapmadığını belirtti. Şiddet kaynağı olarak en fazla hasta yoğunluğu suçlandı. Şiddetin çözümü olarak en slk hasta yoğunluğunun azaltılması önerildi.

Sonuç: Bu sonuçlar daha güvenli hastane ortamı için uygun politikaların ve güvenlik önlemlerinin geliştirilmesinde yardımcı olabilir. Özellikle hasta yoğunluğunun azaltılması ve iletişsim eksikliğinin düzeltilmesine yönelik müdahalelerin uygulanması gereklidir.
\end{abstract}

\section{GíRiș}

Günümüzde şiddet toplumdaki bütün bireyleri ayırım yapmadan etkileyerek nerdeyse günlük yaşamımızın bir parçası haline gelmiştir ve her sektörde önemli bir sorun olarak karşımıza çıkmaktadır (1). Ülkemizde son yıllarda hastanelerde, özellikle de acil servislerde hekimlere karşı şiddet olayları artmakta ve sağlık çalışanları diğer meslek çalışanlarına göre daha fazla şiddete maruz kalmaktadır (2,3). Şiddet sadece hekimler için değil diğer sağlık çalışanları ve hatta hasta ve hasta yakınları için de ciddi bir sıkıntı oluşturabilmektedir (2). Ülkemizde sağlık çalışanlarına uygulanan şiddetle ilgili 1999-2010 tarihleri arasında yayınlanmış 29 yayının değerlendirildiği inceleme
Keywords:

Violence,

Hospital,

Emergency department,

Healthcare workers,

Violence in health.

Anahtar Kelimeler:

Şiddet,

Hastane,

Acil servis,

Sağlık çalışanları,

Sağlıkta şiddet.

sonunda hekim ve hemşirelerin yarıdan fazlasının sözel şiddete ve yaklaşık yedide birinin de fiziksel şiddete uğradıkları belirlenmiştir (4). Bu oranlar dünyanın pek çok ülkesi ile benzerlik göstermekte olup sağlık sektöründeki şiddet uluslararası yaygınlıktadır. Fiziksel, sözel, psikolojik veya cinsel gibi farklı şekilde olabilen şiddet olayları kişisel, kurumsal ve toplumsal boyutta uzun dönemli zararlara sebep olabilir $(5,6)$.

Sağlık sektöründe şiddetin en sık görüldüğü birim acil servislerdir $(7,8)$. Hastanelerin toplumla ilişkisinin en kolay ve fazla olduğu birim olması, 24 saat kesintisiz hizmet verilmesi, geniş klinik tanı yelpazesi, hızla maksimum kapasitesine ulaşması, çoğu zaman multidisipliner bir yaklaşım ve diğer bölümlerle

Correspondence: Yonca Senem Akdeniz, İstanbul Universitesi-Cerrahpaşa, Cerrahpaşa Tıp Fakültesi, Acil Tıp Anabilim Dalı, İstanbul, Turkey. E-mail: ysa@istanbul.edu.tr

Cite this article as: Katran M, Akdeniz YS, Ipekci A, Ikizceli I. A Glimpse of Violence Against Patients And Relatives in the Emergency Department. Phnx Med J. 2020;2(3):160-167. 
koordineli çalı̧̧mayı gerektirmesi, konsültasyon servisler, nerdeyse tüm hastanelerdeki en kalabalık, karmaşı ve stresli birimlerdir (2,9-13).

Acil servis çalışanları da sağlık çalışanları içinde en çok strese maruz kalan gruptur (10). Acil servisin hastaları diğer bölümlerdeki hastalardan her zaman farklılık göstermektedir. Hasta ve yakınlarının ani, beklenmedik bir durumla karşı karşıya kalmaları, ek olarak ağrı, nefes darlığı, kanama gibi klinik belirti ve bulguların varlığı değişik düzeylerde kaygı oluşturmaktadır. Her y1l acil servislere başvuru sayısının artması acil servislerden istek ve beklentilerin de artmasına yol açmaktadır (12). Son yıllarda büyük önem kazanan hasta memnuniyeti, acil servislerin hedeflerinin başlarında gelir ve acil serviste verilen bakımın niteliğini gösteren belirteçlerdendir.

Tablo 1: Sosyodemografik özellikler

\begin{tabular}{|c|c|c|}
\hline & $\mathbf{n}$ & $\%$ \\
\hline \multicolumn{3}{|l|}{ Cinsiyet } \\
\hline Kadın & 107 & 42.8 \\
\hline Erkek & 143 & 57.2 \\
\hline \multicolumn{3}{|l|}{ Yaş grubu } \\
\hline $18-25$ & 70 & 28.0 \\
\hline $26-35$ & 81 & 32.4 \\
\hline $36-45$ & 45 & 18.0 \\
\hline $46-55$ & 27 & 10.8 \\
\hline $56-65$ & 19 & 7.6 \\
\hline 66 ve üzeri & 4 & 1.6 \\
\hline Belirtilmemiş & 4 & 1.6 \\
\hline \multicolumn{3}{|l|}{ Medeni durum } \\
\hline Bekar & 113 & 45.2 \\
\hline Evli & 121 & 48.4 \\
\hline Boşanmış & 16 & 6.4 \\
\hline \multicolumn{3}{|l|}{ Çocuk sayısı } \\
\hline Yok & 137 & 54.8 \\
\hline $1-3$ & 99 & 39.6 \\
\hline 4 ve üzeri & 14 & 5.6 \\
\hline \multicolumn{3}{|l|}{ Eğitim durumu } \\
\hline Okuryazar/ilköğretim & 18 & 7.2 \\
\hline Orta öğretim & 56 & 22.4 \\
\hline Lisans & 129 & 51.6 \\
\hline Yüksek lisans/doktora & 47 & 18.8 \\
\hline \multicolumn{3}{|l|}{ Meslek } \\
\hline Ev hanımı & 30 & 12.0 \\
\hline Öğrenci & 54 & 21.6 \\
\hline Serbest meslek & 44 & 17.6 \\
\hline Diğer & 121 & 48.4 \\
\hline Belirtilmemiş & 1 & 0.4 \\
\hline \multicolumn{3}{|l|}{ Gelir } \\
\hline 0-999 TL & 57 & 22.8 \\
\hline 1000-2999 TL & 94 & 37.6 \\
\hline 3000 TL ve üzeri & 96 & 38.4 \\
\hline Belirtilmemiş & 3 & 1.2 \\
\hline
\end{tabular}

\section{GEREÇ ve YÖNTEM}

$\mathrm{Bu}$ çalışma, İstanbul Üniversitesi Cerrahpaşa Tıp Fakültesi Etik Kurulu'ndan 04.05.2016 tarihinde, 162196 say1 numarası ile onay alındıktan sonra İstanbul Üniversitesi Cerrahpaşa Tıp Fakültesi Acil Tip Anabilim Dalı'nda prospektif anket çalışması olarak gerçekleştirildi. Acil servise başvuran 250 hasta veya hasta yakınına sağlık çalışanı tarafindan uygulandığı iddia edilen şiddet konusunda 33 soruluk bir anket uyguland.

Çalışmaya dâhil edilen kişilerin yaş, cinsiyet, medeni durum, çocuk sayısı, eğitim durumu, meslek, aylık gelir, alkol/sigara/bağımlılık yapan madde kullanımı, bırakma girişimi, psikiyatrik hastalık durumu, intihar girişimi, ailede psikiyatrik hastalık öyküsü, şiddetin özelliklerini ortaya koyabilmek amacıyla şiddetin uygulandığ yer, saat aralığı, şiddetin türü, şiddeti uygulayanın cinsiyeti ve mesleği, şiddete maruz kalma sayısı, şiddetin sonuçlarını ortaya koyabilmek amacıyla şiddete tepki, olay sonrası korku, çaresizlik, dehşet hissi, fiziksel yaralanma ya da sakatlanma durumu, maddi kayıp, olay sonrası yardım alımı, yardım alınan kişi ve tedavi türü, şiddete bakış açısının değerlendirilebilmesi için şiddetin kaynağı ve çözümü ile ilgili düşünceleri, şiddetle ilgili geçmiş deneyimleri ve sonuçlarını da ortaya koyabilmek için hastane dışında da şiddete maruz kalma durumu, kavgada kendini haklı görme durumu, yasal olayla sonuçlanma durumu, şiddete maruziyet durumunun

Tablo 2: Bağımlılık durumu ve psikiyatrik öykü

\begin{tabular}{|l|c|c|}
\hline & $\mathbf{n}$ & $\mathbf{9}$ \\
\hline Alkol/sigara/bağımlılık yapan & & \\
madde kullanımı & $\mathbf{2 5 0}$ & $\mathbf{1 0 0 . 0}$ \\
Yok & 128 & 51.2 \\
Var & 121 & 48.4 \\
Belirtilmemiş & 1 & 0.4 \\
\hline Alkol/sigara/bağımlılık yapan & & \\
madde kullanımı & $\mathbf{1 2 1}$ & $\mathbf{1 0 0 . 0}$ \\
Sigara & 65 & 53.7 \\
Sigara + alkol & 20 & 16.5 \\
Alkol & 13 & 10.8 \\
Sigara + alkol + madde & 1 & 0.8 \\
Belirtilmemiş & 22 & 18.2 \\
\hline Madde bırakma girişimi & $\mathbf{1 2 1}$ & $\mathbf{1 0 0 . 0}$ \\
Yok & 104 & 86.0 \\
Var & 16 & 13.2 \\
Belirtilmemiş & 1 & 0.8 \\
\hline Psikiyatrik hastalık tedavisi & $\mathbf{2 5 0}$ & $\mathbf{1 0 0 . 0}$ \\
Hayır & 231 & 92.4 \\
Evet & 18 & 7.2 \\
Belirtilmemiş & 1 & 0.4 \\
\hline Psikiyatrik hastalık & $\mathbf{1 8}$ & $\mathbf{1 0 0 . 0}$ \\
Depresyon-major depresyon & 15 & 83.3 \\
Anksiyete & 1 & 5.6 \\
Panik bozukluk & 1 & 5.6 \\
Obsesif kompulsif bozukluk & 1 & 5.6 \\
\hline İntihar & $\mathbf{2 5 0}$ & $\mathbf{1 0 0 . 0}$ \\
Hayır & 248 & 99.2 \\
Evet & 1 & 0.4 \\
Belirtilmemiş & 1 & 0.4 \\
\hline Ailede psikiyatrik hastalık & $\mathbf{2 5 0}$ & $\mathbf{1 0 0 . 0}$ \\
Yok & 221 & 88.4 \\
Var & 27 & 10.8 \\
Belirtilmemiş & 2 & 0.8 \\
\hline & & \\
\hline
\end{tabular}


sosyodemografik özellikleri ve psikiyatrik öykü ile ilişkisi değerlendirildi.

Çalışmaya 18 yaş üzerindeki gönüllüler alınırken, akli dengesi yerinde olmayan, bilinç durumunu etkileyen hastalığı olanlar çalışmadan dışlanmıştır.

\section{BULGULAR}

Çalışmaya 18-82 yaş aralığında \%42.8'i (n:107) kadın ve \%57.2'si (n:143) erkek olmak üzere toplam 250 kişi dahil edildi. Katılımcıların çoğu (\%32.4) 26-35 yaş aralığında, evli (\%48.4), çocuksuz (\%54.8) ve lisans mezunuydu (\%51.6) (Tablo 1).

Katılımcıların \%48.4'ünde (n:121) alkol / sigara / bağımlılık yapan madde kullanımı mevcuttu, \%7.2'sinde (n:18) psikiyatrik hastalı tedavisi uygulanmıştı ve \%10.8'inde (n:27) ailede psikiyatrik hastalık öyküsü vardı (Tablo 2). Olguların \%79.2'si (n:198) şiddete uğramadığını belirtirken \%20.4'ü (n:51) şiddete uğradığını belirtti. Şiddet yeri olarak en s1k acil servis (n:22) ve şiddet türü olarak en sık sözlü şiddet (n:46) belirtildi. Şiddet uygulayanın cinsiyeti \%45.1 (n:23) kadın ve \%54.9 (n:28) erkek, şiddet uygulayanın mesleği \%51(n:26) hemşire/ebe/sağlık memuru, olarak belirtildi. (Tablo 3).

Şiddete tepki olarak şiddete uğrayan olgular çoğunlukla bir şey yapmazken, 13'ü hastane idaresine başvurmuş ve 6'sı kendi de şiddet uygulamış (Şekil 1,

Tablo 3: Şiddetin özellikleri

\begin{tabular}{|l|c|c|}
\hline & $\mathbf{n}$ & $\mathbf{9}$ \\
\hline Şiddete uğrama & $\mathbf{2 5 0}$ & $\mathbf{1 0 0 . 0}$ \\
Hayır & 198 & 79.2 \\
Evet & 51 & 20.4 \\
Belirtilmemiş & 1 & 0.4 \\
\hline Şiddet yeri & $\mathbf{5 1}$ & $\mathbf{1 0 0 . 0}$ \\
Acil servis & 22 & 43.1 \\
Poliklinik & 16 & 31.4 \\
Yataklı servis & 10 & 19.6 \\
Diğer & 1 & 2.0 \\
Belirtilmemiş & 2 & 3.9 \\
\hline Şiddetin türü & $\mathbf{5 1}$ & $\mathbf{1 0 0 . 0}$ \\
Sözlü & 46 & 90.1 \\
Sözlü + Fiziksel & 2 & 3.9 \\
Cinsel & 1 & 2.0 \\
Fiziksel & 1 & 2.0 \\
Sözlü + Silah, bıçak tehdidi & 1 & 2.0 \\
\hline Şiddet uygulayanın cinsiyeti & $\mathbf{5 1}$ & $\mathbf{1 0 0 . 0}$ \\
Kadın & 23 & 45.1 \\
Erkek & 28 & 54.9 \\
\hline Şiddet uygulayanın mesleği & $\mathbf{5 1}$ & $\mathbf{1 0 0 . 0}$ \\
Hemşire/ebe/sağlık memuru & 26 & 51.0 \\
Hekim & 13 & 25.4 \\
Güvenlik/sekreter/temizlik memuru & 10 & 19.6 \\
Bilmiyorum & 2 & 4.0 \\
\hline Şiddet zamanı (saat aralığı) & $\mathbf{5 1}$ & $\mathbf{1 0 0 . 0}$ \\
8-16 & 19 & 37.3 \\
16-24 & 19 & 37.3 \\
24-8 & 12 & 23.4 \\
Belirtilmemiş & 1 & 2.0 \\
\hline Şiddete maruz kalma sayısı & $\mathbf{5 1}$ & $\mathbf{1 0 0 . 0}$ \\
1 kez & 26 & 51.0 \\
2-4 kez & 21 & 41.1 \\
5 kez ve üzeri & 3 & 5.9 \\
Belirtilmemiş & & 2.0 \\
\hline
\end{tabular}

Şekil 2, Tablo 4). Şiddet kaynağı olarak en s1k personel, çevresel ve kişisel tüm etkenlerin etkili olduğu belirtildi; bu etkenler içerisinde en fazla hasta yoğunluğu suçlandı. Şiddetin çözümü olarak da en sık hasta yoğunluğunun azaltılması önerildi (Şekil 3, Tablo 5). Şiddete maruz kaldığını belirtenlerde yaş (39.5 \pm 13.6$)$, şiddete maruz kalmadığını belirtenlere (33.9 \pm 12$)$ göre istatistiksel olarak anlamlı derecede daha büyük saptandı $(\mathrm{p}<0.01)$. Ancak demografik veriler, madde kullanımı, bırakma girişimi, psikiyatrik hastalık ve ailede psikiyatrik hastalık öyküsü bakımından istatistiksel olarak anlamlı farklılık bulunmadi $(\mathrm{p}>0.05)$

Katılımcıların hastane dişı şiddete maruz kalması incelendiğinde 32 olgu (\%12.8) hastane dişında şiddete maruz kaldığını belirtti. Hastane dışı şiddete uğrayanların sadece 2'si (\%6.3) s1k s1k şiddete maruz kaldığını ve 8 olgu (\%25) kavgada her zaman kendisinin haklı olduğunu belirtti. Sadece 7 olgu (\%21.9) yasal durumla sonuçlanan olay yaşamış olup 5 olgu şikâyet eden ve 2 olgu şikâyet edilen taraf olduğunu belirtti (Tablo 6).

Hastanede şiddete maruz kalmadığını belirtenlerde hastanede şiddete maruz kaldığını belirtenlere göre hastane dışında şiddete maruziyet istatistiksel olarak

Tablo 4: Şiddetin sonuçları

\begin{tabular}{|c|c|c|}
\hline & $\mathbf{n}$ & $\%$ \\
\hline $\begin{array}{l}\text { Şiddete tepki } \\
\text { Bir şey yapmadım } \\
\text { Hastane idaresine başvurdum } \\
\text { Ben de şiddet uyguladım } \\
\text { Adli makamlara başvurdum } \\
\text { SABİM'e şikayet ettim } \\
\text { Adli makamlara başvurdum + } \\
\text { Ben de şiddet uyguladım } \\
\text { Belirtilmemiş }\end{array}$ & $\begin{array}{c}51 \\
16 \\
13 \\
6 \\
4 \\
1 \\
1 \\
1 \\
10\end{array}$ & $\begin{array}{c}\mathbf{1 0 0 . 0} \\
31.3 \\
25.5 \\
11.8 \\
7.8 \\
2.0 \\
\\
2.0 \\
19.6\end{array}$ \\
\hline $\begin{array}{l}\text { Olayda korku, çaresizlik, } \\
\text { dehşet hissi } \\
\text { Hayır } \\
\text { Evet } \\
\text { Belirtilmemiş } \\
\end{array}$ & $\begin{array}{c}51 \\
32 \\
18 \\
1 \\
\end{array}$ & $\begin{array}{c}\mathbf{1 0 0 . 0} \\
62.7 \\
35.3 \\
2.0 \\
\end{array}$ \\
\hline $\begin{array}{l}\text { Fiziksel yaralanma ya da } \\
\text { sakatlanma durumu } \\
\text { Hayır } \\
\text { Evet } \\
\text { Belirtilmemiş } \\
\end{array}$ & $\begin{array}{c}51 \\
48 \\
2 \\
1 \\
\end{array}$ & $\begin{array}{c}\mathbf{1 0 0 . 0} \\
94.1 \\
3.9 \\
2.0 \\
\end{array}$ \\
\hline $\begin{array}{l}\text { Maddi kayıp } \\
\text { Hayır } \\
\text { Evet } \\
\text { Belirtilmemiş } \\
\end{array}$ & $\begin{array}{c}51 \\
48 \\
2 \\
1\end{array}$ & $\begin{array}{c}\mathbf{1 0 0 . 0} \\
94.1 \\
3.9 \\
2.0 \\
\end{array}$ \\
\hline $\begin{array}{l}\text { Olay sonrası yardım alımı } \\
\text { Hayır } \\
\text { Evet } \\
\text { Belirtilmemiş } \\
\end{array}$ & $\begin{array}{c}51 \\
40 \\
9 \\
2 \\
\end{array}$ & $\begin{array}{c}\mathbf{1 0 0 . 0} \\
78.4 \\
17.6 \\
3.9 \\
\end{array}$ \\
\hline $\begin{array}{l}\text { Yardım alınan kişi } \\
\text { Psikolog } \\
\text { Pratisyen hekim } \\
\text { Psikiyatri uzmanı } \\
\text { Diğer }\end{array}$ & $\begin{array}{l}9 \\
4 \\
2 \\
2 \\
1\end{array}$ & $\begin{array}{c}100.0 \\
44.4 \\
22.2 \\
22.2 \\
11.2 \\
\end{array}$ \\
\hline $\begin{array}{l}\text { Tedavi türü } \\
\text { Tedavi yok } \\
\text { Psikolojik } \\
\text { Farmakolojik } \\
\text { Diğer }\end{array}$ & $\begin{array}{l}9 \\
3 \\
3 \\
1 \\
2\end{array}$ & $\begin{array}{l}\mathbf{1 0 0 . 0} \\
33.3 \\
33.3 \\
11.2 \\
22.2\end{array}$ \\
\hline
\end{tabular}



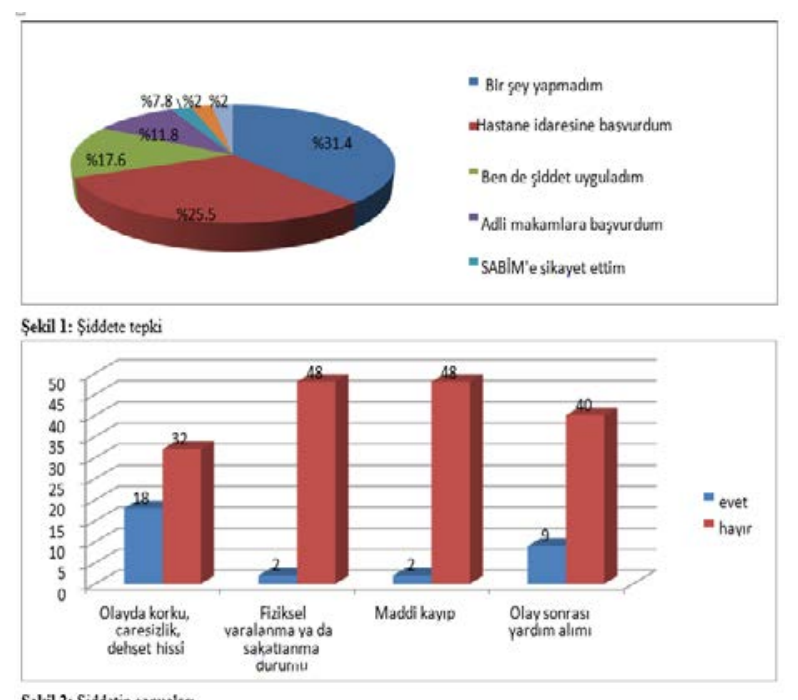

Sekil 2: Șiddetin sonuclarr

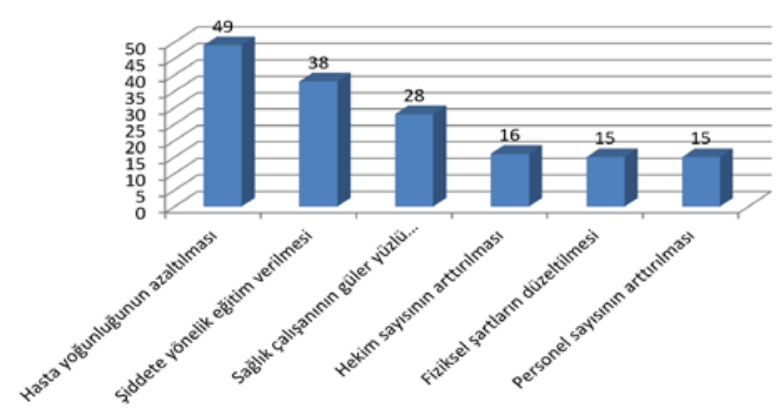

Şekil 3: Şiddet çözüm önerileri

anlamlı derecede daha yüksek bulundu $(\mathrm{p}<0.05)$ (Tablo 7).

\section{TARTISSMA}

Hastanelerde, özellikle acil servis gibi özel alanlarda hizmet veren hekim ve diğer personeller, hatta hasta ve hasta yakınları da şiddet riski altındadır (2,3). ABD'de sağlık sektöründe şiddete uğrama riskinin diğer hizmet sektörlerindeki çalışanlara göre 16 kat daha fazla olduğu saptanmıştır (1). ABD'de 1988 yllında yapılan bir çalışmada 127 acil servis yöneticisinden elde edilen bilgilere göre hastanede günde en az 1 sözlü tehdit $\% 32$, ayda en az 1 silahlı tehdit \%18 oranlarında görülmüştür. Beş yıllık bir izlemde ise hastanede personelin silahlı tehdidi \%57, acil servis personelinin ayda en az $1 \mathrm{kez}$ fiziksel saldırıya maruz kalması $\% 43$, hastanede personelin yaralanmas1 $\% 80$ ve hastanede ölüm \%7 oranlarında saptanmıştır (14). Dünya Sağlık örgütü (WHO), Uluslararası çalışma örgütü (ILO) ve Uluslararası Hemşireler Birliği (ICN)'nin 2002 y1lı "sağlık sektöründe iş yeri şiddeti" başlıklı ortak raporunda sağlık çalışanlarının işleri sırasında \%317'sinin fiziksel, \%27-67'sinin sözel, \%10-23'ünün psikolojik, \%0.7-0.8'inin cinsel içerikli, \%0.8-2.7'sinin etnik şiddete maruz kaldıkları bildirilmektedir (15). Bizim çalı̧̧mamızda ise acil servise başvuran hasta veya hasta yakınlarına sağlık çalışanları tarafından uygulandığı iddia edilen şiddetin özellikleri incelendi
Tablo 5: Şiddet kaynağı ve çözüm önerileri

\begin{tabular}{|l|c|c|}
\hline & $\mathbf{n}$ & $\mathbf{9}$ \\
\hline Şiddet kaynağı & $\mathbf{2 5 0}$ & $\mathbf{1 0 0 . 0}$ \\
Personel + Çevresel + Kişisel & 58 & 23.2 \\
Personel + Çevresel & 6 & 2.4 \\
Çevresel + Kişisel & 5 & 2.0 \\
Personel & 3 & 1.2 \\
Kişisel & 2 & 0.8 \\
Personel + Kişisel & 2 & 0.8 \\
Belirtilmemiş & 174 & 69.6 \\
\hline Personele bağlı nedenler & $\mathbf{1 0 9}$ & $\mathbf{4 3 . 6}$ \\
Sağlık çalışanının iletişim eksikliği & 32 & 12.8 \\
Sağlık çalışanının kaba davranması & 31 & 12.4 \\
Sağlık çalışanının sabırsız davranışı & 30 & 12.0 \\
Sağlık çalışanının & & \\
eğitim yetersizlikleri & 12 & 4.8 \\
Sağlık çalışanının güç & & \\
gösterisi yapması & 4 & 1.6 \\
\hline Çevresel nedenler & $\mathbf{8 8}$ & $\mathbf{3 5 . 2}$ \\
Hasta yoğunluğu & 45 & 18.0 \\
Hastane personelinin uzun ve yoğun & 43 & 17.2 \\
çalışma süreleri & & \\
\hline Kişisel nedenler & $\mathbf{1 0 2}$ & $\mathbf{4 0 . 8}$ \\
İletiş̧im eksikliği & 39 & 15.6 \\
Hasta ve yakınının hastane kurallarına & & \\
uymak istememesi & 22 & 8.8 \\
Hasta ve yakınının eğitim yetersizlikleri & 18 & 7.2 \\
Sabırsı ve talepkar tutumlar & 16 & 6.4 \\
Hasta ve yakınının güç gösterisi & & \\
yapması & 7 & 2.8 \\
\hline Şiddet çözümü & $\mathbf{1 6 1}$ & $\mathbf{6 4 . 4}$ \\
Hasta yoğunluğunun azaltılması & 49 & 19.6 \\
Şiddete yönelik eğitim verilmesi & 38 & 15.2 \\
Sağlık çalşsanının güler yüzlü olması & 28 & 11.2 \\
Hekim sayısının arttırılması & 16 & 6.4 \\
Personel sayısının arttırılması & 15 & 6.0 \\
Fiziksel şartların düzeltilmesi & 15 & 6.0 \\
\hline
\end{tabular}

ve katılımcıların \%79.2'si (n:198) şiddete uğramadığını belirtirken \%20.4'ü (n:51) şiddete uğradığını belirtti. Yirmi altı olgu bir kez, 21 olgu 2-4 kez ve 3 olgu 5 kez ve üzeri şiddete maruz kaldığını belirtti.

Ayrancı ve ark. yaptı̆̆ çalışmada şiddet olaylarının \%63.1'inin acil servislerde ve kurum olarak ta \%63.1'inin devlet hastanesinde meydana geldiği saptanmışıır (16). 2011 yilında 12 ilde yapılan bir çalışmada ise katılımcıların \%68.8'inin şiddet ile devlet hastanesinde karşılaştığ belirlenmiştir (17). Daha az sıklıkla bekleme alanları, park yeri, koridor ve kafeteryalar da şiddetin görülebileceği yerler olarak bildirilmiştir (18). Dahili ve cerrahi kliniklerinde de şiddetin nadir olmadığ Çalışmamızda da şiddete uğrama yeri olarak en sık acil servis (n:22) belirtildi. Acil serviste tıbbi hata yapma korkusu, ani ölümlerle karşılaşma, ölen hastanın yakınlarıyla uğraşma, kaba ve düşmanca tutum sergileyebilen insanlarla ilgilenme zorunluluğu ve güvenlik endişesi başlica iş stres faktörleridir $(10,20,21)$. Acil servise başvuranların kaba ve düşmanca tutumu bu stresin en önemli kaynaklarından birisidir $(10,20)$. Bunların neticesinde "Tükenmişlik Sendromu" dediğimiz durum ortaya çıkmakta ve hekimlerin performansları olumsuz etkilenerek iş verimliliği azalmaktadır $(4,22)$. Bu durum da kesintisiz ve ekip işi gerektiren acil servis hizmetlerinde aksamaya yol açmaktadır. 
Tablo 6: Hastane diși şiddet durumu

\begin{tabular}{|l|c|c|}
\hline & $\mathbf{n}$ & $\mathbf{\%}$ \\
\hline Hastane dışı şiddete maruz kalma & $\mathbf{2 5 0}$ & $\mathbf{1 0 0 . 0}$ \\
Hayır & 54 & 21.6 \\
Evet & 32 & 12.8 \\
Belirtilmemiş & 164 & 65.6 \\
\hline Sıklık & $\mathbf{3 2}$ & $\mathbf{1 0 0 . 0}$ \\
Nadiren (1-2 yılda bir) & 25 & 78.1 \\
Bazen (3-4 ayda bir) & 5 & 15.6 \\
Sık sık & 2 & 6.3 \\
\hline Kavgada & $\mathbf{3 2}$ & $\mathbf{1 0 0 . 0}$ \\
Her zaman haklı olduğumu düşünüyorum & 8 & 25.0 \\
Kimi zaman ben, kimi zaman karşı taraf haklı & 24 & 75.0 \\
Çoğu zaman ben gereğinden fazla tepki & & \\
gösteriyorum & 0 & 0.0 \\
\hline Yasal durumla sonuçlanan olay yaşama & $\mathbf{3 2}$ & $\mathbf{1 0 0 . 0}$ \\
Hayır & 25 & 78.1 \\
Evet & 7 & 21.9 \\
\hline Hangi taraftasınız & $\mathbf{7}$ & $\mathbf{1 0 0 . 0}$ \\
Şikâyet eden & 5 & 71.4 \\
Şikâyet edilen & 2 & 28.6 \\
\hline
\end{tabular}

Şiddetin en yaygın nedenleri olarak hasta yoğunluğu, uzun bekleme süresi, 24 saat kesintisiz hizmet verilmesi, hasta ve yakınlarının gerçekçi olmayan beklentilerde bulunması, sinirli aile üyelerinin varlığı, hastanın ölümü, servis kuralları, ödeme zorlukları, personel sayısının yetersizliği, çalışanın şiddet karşısında nasıl davranacağını bilememesi, yeterli sayıda güvenlik elemanının olmaması ve şiddeti önlemeye yönelik etkili kurumsal ve yasal düzenlemelerin olmaması sayılmaktadır (2,4,13,23-25). Gelişen sıkıntılarda hastanın her daim haklı kabul edilmesi veya olaya medyatik ve popülist yaklaşımlarla çalışanlar ile hastaların karşı karşıya getirilmesi de şiddet için ciddi alt yapı oluşturabilmektedir $(2,6)$.

Bekleme zamanı, hasta memnuniyeti için en önemli faktördür (12). Ankara'da yapılan bir çalışmada sağlık kurumlarına başvuran kişilerin \%62.7'si sağlık çalışanlarının şiddete maruz kalma durumuna muayene sirasında fazla beklemenin neden olduğunu ifade etmiştir (13). İsrail'deki bir çalışmada da şiddet sebebi \%46.2 olarak uzun bekleme süresidir (15). Çalışmamızda şiddet kaynağı olarak en sık personel, çevresel ve kişisel tüm etkenlerin birlikte etkili olduğu belirtildi; bu etkenler içerisinde hasta veya hasta yakınlarına göre en fazla hasta yoğunluğu suçlandı.

Şiddet uygulayanlara bakıldığında daha çok erkek, 30 yaş ve altı, eğitim düzeyi düşük, yasal ya da yasadış1 olarak silah bulundurabilen ve psikiyatrik hastalığ olan, alkol veya madde bağımlısı kişiler olduğu belirtilmektedir $(4,14)$. Otorite ile sorunları olan kişiler de bu gruptandır. Tıbbi ve psikiyatrik hastalıkların varlığı da saldırganlığı etkilemektedir. Ancak şiddet uygulama eğilimi açısından psikolojik veya psikiyatrik olmadığı bildirilmektedir (26). Çalışmamızda olguların \%48.4'ünde alkol/sigara/bağımlılık yapan madde kullanımı mevcuttu ve \%7.2'sinde psikiyatrik hastalık tedavisi uygulanmıştı. Olguların \%10.8'inde ailede psikiyatrik hastalık öyküsü vardı. Şiddete maruz kaldığını belirtenler ile şiddete maruz kalmadığını
Tablo 7: Hastanede şiddete maruziyet ile hastane dişı şiddete maruziyet durumu arasındaki ilişki

\begin{tabular}{|c|c|c|c|c|c|}
\hline \multirow[b]{2}{*}{$\begin{array}{l}\text { Hastane dışı } \\
\text { şiddete maruziyet }\end{array}$} & \multicolumn{2}{|c|}{$\begin{array}{l}\text { Hastanede şiddete } \\
\text { maruz kalma yok }\end{array}$} & \multicolumn{2}{|c|}{$\begin{array}{l}\text { Hastanede şiddete } \\
\text { maruz kalma var }\end{array}$} & \multirow{2}{*}{$\mathbf{p}$} \\
\hline & $\mathbf{n}$ & $\%$ & n & $\%$ & \\
\hline Hayır & 20 & 51.3 & 34 & 72.3 & \multirow{2}{*}{0.044} \\
\hline Evet & 19 & 48.7 & 13 & 27.7 & \\
\hline
\end{tabular}

belirtenler arasında alkol/sigara/bağımlılık yapan madde kullanımı, bırakma girişimi, ailede ve kişide psikiyatrik hastalık ve ailede öyküsü bakımından anlamlı fark bulunmad.

İngiltere'de yapılan bir çalışmada devlet hastanesinde katılımcıların \%68'i sözel şiddete maruz kaldığını, ABD'de yapılan bir çalışmada acil serviste çalışan hekimlere sözel şiddet sıklığı \%74.9, Türkiye genelinde ise bu s1klık \%53.7-\%60 olarak bildirilmiştir (27-30). Ülkemizde daha yüksek oran bildiren çalışmalar da mevcuttur. Adana ilindeki acil servislerdeki bir çalışmaya göre katılımcıların hepsi her nöbetinde en az bir kez sözel şiddete maruz kalmaktadır (31). Sağlık kurumlarına başvuran kişilerin dâhil edildiği çalışmada \%79.4'ü sağlık çalışanlarının en sık sözel şiddete maruz kaldığını belirtmiştir (13). Çalışmamızda da şiddet türü olarak en sık sözlü şiddet belirtildi (32-37). Sözel şiddet s1klığının tüm çalışmalarda yüksek çıkması cezasının az olması, kanıtlanabilirliğinin daha zor olması, bildirimlerin daha az yapılması ve sözel şiddet nedeniyle cezanın hak edilmediği düşüncelerinden kaynaklanıyor olabilir.

Bazı çalışmalarda kadın cinsiyetin sağlık çalışanları arasında da daha fazla şiddete uğradıkları gösterilmiştir $(4,38,39)$. Şiddetin türüne göre ise genellikle sözel şiddete uğramada kadınların, fiziksel şiddete uğramada erkeklerin çoğunlukta olduğu belirtilmiştir $(4,40)$. Kadın sağlık çalışanlarına sözel şiddetin fazla olmasının nedenleri olarak kadınların savunmasız olarak algılanması, kadınların tepkisinin erkeklere göre daha az olması ve ataerkil toplum gereği kadınların tepkilerine daha fazla tepki gösterilmesi sayılabilir (13). Çalışmamızda şiddet uyguladığı iddia edilen kişilerin cinsiyeti \%45.1 kadın ve \%54.9 erkek, şiddete uğradığını iddia edenlerin \%42.8'i kadın ve \%57.2'si erkek olarak belirtildi. Ancak şiddete maruz kaldığını belirtenler ile şiddete maruz kalmadığını belirtenler arasında cinsiyet bakımından anlamlı fark bulunmadı

Meslek gruplarına göre incelendiğinde şiddete uğrama konusunda hemşirelerin en riskli grup olduğu belirlenmiştir (4,39,40). 2002 yılında Eskişehir, Ankara ve Kütahya'da birinci basamakta, devlet hastanesinde ve üniversite hastanesinde çalışanların dâhil edildiği çalışmada erkeklerin \%48 ve kadınların \%52.5'i son bir yıl içerisinde şiddete uğradığını ifade etmiştir. Şiddete en çok hemşire ve pratisyen hekimlerin uğradığı, en az ise öğretim görevlilerinin maruz kaldığ saptanmıştır (16). 2009 yılında Ankara'da bir üniversite hastanesinde yapılan çalışmada intern 
doktorların \%65.5'i ve araştırma görevlisi doktorların $\% 59.5$ 'i çalışma yaşamı boyunca en az bir defa şiddete uğradıklarını belirtmişlerdir (41). Çalışmamızda şiddet uygulayanın mesleği de en sık hemşire/ebe/sağlık memuru, 2. siklikta hekim ve 3.s1klikta güvenlik/sekreter/temizlik memuru olarak belirtildi. Bu sonuçlara göre hasta veya hasta yakınları ile en fazla temas eden personel olması nedeniyle hemşirelerin daha fazla risk altında olduğu düşünülmektedir.

Şiddetin gerçekleştiği saat aralığı incelendiğinde, Aydın ve ark. çalışmasında sağlık çalışanlarının şiddete uğrama saati $\% 45$ oranında gündüz çalışma saatleri olarak bildirilmiştir (42). Öztunç ve ark. ise yaptıkları çalışmada gündüz mesaisinde çalışan hemşirelerin şiddete daha fazla uğradıklarını saptamışlardır (43). Bazı çalışmalarda şiddet gece mesailerinde daha fazla görülmüş ve en sık saat aralığının ise 16.00-20.00 olduğu saptanmıştır $(8,44)$. Çalışmamızda da şiddet kaynağ1 olarak en fazla suçlanan faktör olan hasta yoğunluğunun daha fazla olduğu saatlerde şiddetin de daha fazla gerçekleştiği saptandı; şiddetin uygulandiğ 1 zaman en s1k saat $08-16$ ve $16-24$ arası sonrasinda ise saat 24-08 arası olarak belirtildi.

Yapılan çalışmalarda şiddet olayına verilen tepkiler incelendiğinde saldırı mağdurlarda olay sonrası en sık duygusal ve fizyolojik belirtiler görüldüğü $(4,6)$ ve genelde de baş etmede yetersiz kalındığ (4). Başka bir çalışmada şiddete uğrayanların \%78.1'inin şiddete karşılık verdiği saptanmıştır (25). Çalışmamızda katılımcılarının çoğu olayda korku, çaresizlik, dehşet hissettiğini, iki kişi fiziksel yaralanma ya da sakatlanma yaşadığını ve yine iki kişi maddi kayıp yaşadığını belirtti. Dokuz kişi olay sonrası yardım almıştı. Sağlık kurumlarında görülen şiddetin bildiriminin az olduğu, sadece yaralanma gibi ciddi fiziksel şiddet olayların şiddet olarak algılandığı, diğer olaylarının bildirilmediği tespit edilmiştir $(6,45,46)$. Genellikle sözel şiddet olayları ciddi bir sorun olarak değerlendirilmemekte ya da bildirim sonrası bürokratik engellemeler nedeniyle sonuç alamama endişesi ile bildirimde bulunulmamaktadır $(19,47)$. Ülkemizde de yapılan çalışmalarda sağlık çalışanlarının \%67'sinin, hekimlerin \%62'sinin, acil servis çalışanlarının ise \%60'ının şiddete maruz kalma sonrasında herhangi bir şikâyette bulunmadıkları belirlenmiştir. Çalışanların şikâyette bulunmama gerekçeleri içinde en başta idari yöneticilere ve adalet mekanizmasına karşı güvensizlik, yanıt almadaki bürokratik engeller olduğu belirtilmiştir (42). Birçok çalışma, çalışırken saldırıya uğramanın mesleğin bir parçasıymış gibi algılanması ve bu nedenle olayların bildirilmeme eğilimi olduğunu da ifade etmektedir $(14,39)$. İşyerlerinde şiddete uğrama durumunun bildirilmesinde bu eksiklikler ve engeller olduğu için gerçek sıklığın net olmadığı, sadece bildirilen olgularla sınırlı kaldığı belirtilmiştir (48). Gerçekleşen olayların çoğu kayıt altına alınmamakla birlikte hastane yönetimlerinin acil servisteki şiddet olaylarından bir şekilde zarar gören ya da yaralanan hasta ve yakınları tarafından dava edilebildiğini görmekteyiz (2). Çalışmamızda da şiddete tepki olarak benzer şekilde şiddete uğrayan olgular en sık bir şey yapmazken, 13'ü hastane idaresine başvurmuş, 4'ü adli makamlara başvurmuş, 1'i SABİM'e şikâyet etmiş, 6'sı kendi de şiddet uygulamış ve 1 'i hem kendi de şiddet uygulamış hem de adli makamlara başvurmuştu. Şiddetin sıklığı ve boyutu ile ilgili en sağlam kanıtların elde edilebilmesi yaşanan olayların bildirilmesi ile mümkün olacaktır.

Yaşamın her alanında olduğu gibi sağlık sektöründe de şiddet ile ilgili gerekli önlemlerin alınması gerekmektedir. Acil servis hemşireleri ile yapılan bir çalışmada şiddetin çözümü ile ilgili öneri olarak hemşire ve hastanın yöneticilerce ayrı ayrı dinlenmesi (\%29.34), acil serviste yeterli sayıda ve nitelikte personelin çalıştırılması (\%18.48), şiddet uygulayan hasta ve yakınlarına gerekli yaptırımların uygulanması (\%11.96) önerilerini getirdikleri tespit edilmiştir (49). Başka bir çalışmada yine acil serviste şiddetin çözümü ile ilgili olarak "acil serviste kalan hastaların yatışı ile ilgili yazılı kuralların belirlenmesi", "güvenlik önlemlerinin arttırılması", "konsültasyon işlemlerinin yazılı hale getirilip hekimlere resmi tebliğinin yapılması", "acil hekimlerine hizmet içi eğitimler verilmesi" ve "fiziki alan ve personel kapasitesinin arttırılması" katılımcıların en s1k önerileri olmuştur (21). Katılımcıların sağlık kurumlarına başvuran kişiler olduğu bir çalışmada ise sağlık çalışanına uygulanan şiddetin önlenmesi için katılımcıların \%68.4'ü gerekli yasal düzenlemeler hazırlanması ve \%66.7'si halka yönelik eğitimler verilmesi önerisinde bulunmuştur. $\mathrm{Bu}$ yanıtlara şiddet olaylarına karışanlara ceza verilmemesi ya da verilen cezaların yetersiz görülmesi, medyaya yansıyan şiddet olaylarının artması ve şiddetin hayatın her alanında görünür hale gelmesinin neden olabileceği düşünülmektedir. Aynı çalışmada şiddet görenlerin görmeyenlere göre sağlık çalışanlarına karşı olan şiddetin önleneceğine olan inançlarının daha az olduğu ve bunun umutsuzluklarından kaynaklandığ düşünülmüştür (13). Çalışmamızda da hasta veya hasta yakınları tarafından şiddetin çözümü olarak en sık hasta yoğunluğunun azaltılması önerildi; daha sonra sırasıyla şiddete yönelik eğitim verilmesi, sağlık çalışanının güler yüzlü olması, doktor ve personel sayısının arttırılması ve fiziksel şartların düzeltilmesi önerilerinde bulunuldu.

Ülkemizde sağlık hizmetlerinde şiddete yönelik herhangi bir yasal/organizasyonel düzenlemenin olmaması, şiddetin önlenmesi ve güvenliğinin sağlanması konusunda boşluklar oluşmasına ve saldırı olaylarının çoğunun bildirilmemesine, dolayısıyla bu konudaki gerçek sayısal verilerin bilinmemesine neden olmaktadır (4). Katılımcıların sağlık kurumlarına başvuran kişiler olduğu çalışmada katılımcıların yaklaşık \%70'inin sağlık çalışanına şiddet uygulayanlara ceza uygulanmadığını düşündüğü saptanmıştır (13). Bu duruma medyada sağlık çalışanlarına şiddet uygulandığ yaptırımın olmadığı ile ilgili çok sayıda haberin neden olabildiği düşünülmüştür. Aynı çalışmada incelenenlerin \%20'sinin de çalışanın şiddeti hak 
ettiğini düşündüğü saptanmıştır ve bunun nedeni olarak en çok hastayla yeterince ilgilenilmemesi tespit edilmiştir (13). Hasta ve hasta yakınlarının sağlık çalışanlarından beklentisinin çok fazla olması, bu beklentileri tam olarak gerçekleşmeyince şiddete başvurmaları ve bunu kendilerine hak olarak görmeleri önemli bir problemdir.

Şiddet türleri konusunda tam bir dil ve tanım birliğinin olmadığı ve şiddet türlerinin hangi davranışları içerdiği konusunda kültürel ve bireysel farklıklar olduğu da bilinmektedir (4). Ülkemizde sağlık çalışanlarına yönelik şiddetle ilgili yayınlanmış 29 yayının değerlendirildiği inceleme sonucunda hemşireler için bildirilen fiziksel saldırı ortalaması \%17.7 iken, İngiltere'de yapılan bir çalışmada hemşirelerin \%97'sinin son bir yıl içinde fiziksel şiddete uğradığı rapor edilmiştir $(1,4)$. Oranlardaki farklılığın fiziksel şiddetin kültürlerarası tanımlanmasındaki farklılıklardan kaynaklandığı düşünülmektedir. Bizim kültürümüzde fiziksel saldırı kapsamında değerlendirilmeyen pek çok davranış batı kültüründe fiziksel saldırı olarak tanımlanabilmektedir (4). Çalışmamızda katılımcıların hangi davranışları şiddet olarak kabul ettiği ve iddia ettikleri olayların gerçekten şiddet olup olmadığı belirsizdir. Veriler önceki çalışmalarda da olduğu gibi kişilerin geçmiş deneyimlerine odaklanıp saldırı bildirme raporlarına dayandırılmamıştır. $\mathrm{Bu}$ durumda kişilerin geçmiş deneyimleri konusunda ön yargılı davranabilecekleri de göz önünde bulundurulmalıdır. Bu güçlüklere rağmen sonuçlar sağlık sektöründe şiddetin ciddi bir sorun olduğuna işaret etmektedir. Sağlik sektöründe şiddete hasta yakınlarının bakış açısını gösteren nadir çalışmalardan biri olması nedeniyle bu çalışmamız, literatüre bir katkı olarak sunulmuştur. Bundan sonra yapılacak çalışmalarda şiddet tip ve özelliklerinin tanımlanması için ortak bir dilin oluşturulması, standart ölçeklerin geliştirilmesi ve uygulanması önerilmektedir.

Sonuç olarak, öncelikle toplumsal müdahalelerle şiddet azaltılmaya çalışılmalıdır. Şiddetle ilgili yasal düzenlemeler yapılmalı ve uygulanmalıdır. Şiddetin nedenleri saptanmalı ve nedenlere yönelik stratejiler geliştirilmelidir. Hastaneler kendi iç güvenlik sistemlerini kurmalıdır. Hasta ve yakınlarına göre şiddetin en sik nedeni olarak belirtilen hasta yoğunluğunun azaltılması için hastanede yeterli sayıda ve kalitede eleman görevlendirilmeli, tetkik, konsültasyon ve sevk işlemlerini hızlandıracak müdahalelerle hastaların hastanede kalış süresi kısaltılmalı ve özellikle acil servise gereksiz başvuruların önüne geçilebilmesi konusunda toplum bilinçlendirilmelidir. Acil serviste ve hatta hastane ortamında çalışan her çalışanın hasta veya hasta yakınları ile iyi iletişim kurma, doğru bilgilendirme, profesyonel davranış ve saldırgan kişilere yaklaşım konusunda eğitilmeleri gereklidir. Şiddet ve şiddetin çözümü ile ilgili halka yönelik seminerler düzenlenmeli, eğitim verilmeli, özellikle muayene sırasında beklenebileceği bilinci yerleştirilmelidir. Çoğunlukla olumsuz ve özellikle şiddet olayları ile medyada gündeme gelen sağlık çalışanları ile ilgili olumlu haberlerin de gündeme getirilmesi ve şiddete yönelik kamu spotlarının yayınlanması da faydalı olacaktır. $\mathrm{Bu}$ önerilerle şiddet azaltılarak özellikle kesintisiz hizmet vermek zorunda olan ve ekip çalışması gerektiren acil servislerde sağlık personelinin performansı olumlu etkilenecek ve hizmet kalitesi de artmış olacaktır.

\section{Çıkar İlişkisi}

Tüm yazarlar çıkar çatışması olmadığını beyan eder.

\section{KAYNAKLAR}

1. Kingma M. Workplace violence in the health sector: a problem of epidemic proportion. Int Nurs Rev. 2001;48(3):129-30.

2. Aktuğlu, K, Hancı, H. Acil Serviste Şiddet Tehdidi. Hekimin Yasal Sorumluluk ve Hakları (Tıp ve Sağlık Hukuku). Ege Üniversitesi Tıp Fakültesi, Toprak Ofset, İzmir. 1999; s: 1-7.

3. Tekin İ. Acil hekimlerine yönelik șiddet. Turkiye Klinikleri J Surg Med Sci. 2006;2(50):68-73.

4. Keser Özcan N, Bilgin H. Türkiye'de sağlık çalışanlarına yönelik şiddet: sistematik derleme. Turkiye Klinikleri J Med Sci. 2011;31(6):1442-56.

5. Rippon TJ. Aggression and violence in health care proffessions. J Adv Nurs. 2000;31(2):452-60

6. Farrell GA, Bobrowski C, Bobrowski P. Scoping workplace aggression in nursing: findings from an Australian study. J Adv Nurs. 2006;55(6):778-87.

7. Gülalp B, Karcıoğlu O, Köseoğlu Z, Sarı A. Dangers faced by emergency staff: experience in urban centers in southern Turkey. Ulus Travma Acil Cerrahi Derg. 2009;15:239-42.

8. Lau J, Magarey J, McCutcheon H. Violence in the emergency department: A literature review. Aust Emerg Nurs J. 2004;7:27-37.

9. Genç MF, Eğri M, Pehlivan E, Kırımlıŏlu V, Yılmaz S. Acil servise başvuran hastaların bekleme zamanları üzerine bir çalışma. Turgut Özal Tıp Merkezi Dergisi. 1999;6(4):337-9.

10. Serinken M, Tomruk Ö, Erdur B, Soysal S, Çımrın AH. Acil servis hekimlerinin iş stres faktörleri. Akademik Acil Tıp Dergisi. 2003;2:4851.

11. Barber Perez P, Gonzalez Lopez-Valcarcel B. Stimulation of a hospital emergency department and its potential use in management. Gac Sanit. 1994;8:239-47.

12. Karaca MA, Erbil B, Özmen MM. Waiting in the emergency room: patient and attendant satisfaction and perception. Eur J Surg Sci. 2011;2(1):1-4.

13. İlhan MN, Cakır M, Tunca MZ, Avcı E. Toplum gözüyle sağlık çalışanlarına şiddet: nedenler, tutumlar, davranışlar. GMJ. 2013;24:5-10

14. Ordog GJ, Wasserberger J, Ordog C, Ackroyd G, Atluri S. Weapon carriage among major trauma victims in the emergency department. Acad Emerg Med. 1995;2(2):109-13.

15. Nau J, Halfens R, Needham I, Dassen T. The de-escalating aggressive behaviour scale: development and psychometric testing. J Adv Nurs. 2009;65(9):1956-64. 
16. Ayrancı U, Yenilmez C, Gunay Y, Kaptanoğlu C. Çeşitli sağlık kurumlarında ve sağlık meslek gruplarında şiddete uğrama sıklığı. Anadolu Psikiyatri Dergisi. 2002;3:147-54.

17. Yıldırım HH, Kalem M, Seyran F, Demiray FN. Sağlık İşyeri Ortamında Şiddet: Halkın Şiddet Algısı ve Değerlendirmeleri, Ön Bulgular Raporu, www.sağlıksen.org.tr, Ankara-2011.

18. Barlow CB and Rizzo AG. Violence against surgical residents. West J Med. 1997;167:74-8.

19. Hesketh KL, Duncan SM, Estabrooks CA, Reimer MA, Giovannetti P, Hyndman K, et al. Workplace violence in Alberta and British Columbia Hospitals. Health Policy. 2003;63(3):311-21.

20. Whitehead DC, Pines A. Surviving The 10-Year Ache: Emergency Practice Burnout. Emergency Medicine Reports(Supplement). 1991;23:1-7.

21. Çıkrıklar Hİ, Yürümez Y, Yücel M, Asan Aslan N, Engindeniz Z, Cebicci H, Altuntaş M. Acil serviste zor hastaların yönetimi. Sakarya Tip Dergisi. 2016;6(1):20-6.

22. Bircan M, Ak A, Bayrak D, Kaya H, Gül M, Cander B. Acil tıp hizmeti veren hekimlerde tükenme sendromu. Akademik Acil Tıp Dergisi. 2006;4(7):51-4.

23. Hahn S, Zeller A, Needham I, Kok G, Dassen T, Halfens RJG. Patient and visitor violence in general hospitals: a systematic review of the literature. Aggr Viol Behav. 2008;13(6):431-41.

24. Carmi-Iluz T, Peleg R, Freud T, Shvartzman P. Verbal and physical violence towards hospital and community-based physicians in the Negev: an observational study. BMC Health Serv Res. 2005;5:54.

25. Camcı O, Kutlu Y. Kocaeli’nde sağlık çalıșanlarına yönelik ișyeri şiddetinin belirlenmesi. Psikiyatri Hemşireliği Dergisi. 2011;2:9-16.

26. Young GP. The agitated patient in the emergency department. Emerg Med Clin North Am. 1987;5(4):765-81.

27. Winstanley S. Whittington R. Aggression towards health care staff in a UK general hospital: Variation among professions and departments, J Clin Nurs. 2004;13:3-10.

28. Kowalenko T, Walters BL, Khare RK, Compton S. Michigan College of Emergency Physicians Workplace Violence Task Force Workplace violence: a survey of emergency physicians in the state of Michigan. Ann Emerg Med. 2005;46:142-7.

29. Ayranci U, Yenilmez C, Balci Y, Kaptanoglu C. Identification of violence in Turkish health care settings. J Interpers Violence. 2006;21:276-96.

30. Acık Y, Deveci SE, Guneş G, Gulbayrak G, Dabak Ş, Saka G, et al. Turkiye'de Tıp Fakültelerinde Uzmanlık Eğitimi Almakta Olan Hekimlerin Sözel, Fiziksel ve Cinsel Şiddete Maruz Kalma Sıklığı. IX. Halk Sağlı̆̆ı Kongre Bildiri Ozetleri Kitabı, GATA, 2005; 185: 415.

31. Gülalp B, Karcioğlu O, Köseoğlu Z, Sari A. Dangers faced by emergency staff: experience in urban centers in southern Turkey. Ulus Travma Acil Cerrahi Derg. 2009;15:239-42.

32. Tengilimoğlu D. Ankara'da bir üniversite hastanesinde hasta memnuniyetinin ölçülmesi. Çoruh M, editör. Sağlık hizmetlerinde toplam kalite yönetimi ve performans ölçümü. Ankara: Haberal Eğitim Vakfi; 1997. p: 103-11.

33. Thompson DA, Yarnold PR, Williams DR, Adams SL. Effects of actual waiting time, perceived waiting time, information delivery, and expressive quality on patient satisfaction in the emergency department. Ann Emerg Med. 1996;28:657-65.

34. Fottler MD, Ford RC. Managing patient waits in hospital emergency departments. Health Care Manag (Frederick). 2002;21: 46-61.

35. Rondeau KV. Managing the clinic wait: an important quality of care challenge. J Nurs Care Qual. 1998; 13: 11-20.

36. Mowen JC, Licata JW, McPhail J. Waiting in the emergency room: how to improve patient satisfaction. J Health Care Mark. 1993;13:2633.

37. Okay A. Sağlık İletişimi. İstanbul: Der Yayıncılık. 2020. p: 8-9

38. Aslan FE. A study related to the determination of the present case of the emergency trauma units in Istanbul. Nursing Forum. 1999;2(4):175-93.

39. Jakson M, Ashley D. Physical and psychological violence in Jamaica’s health sector. Rev Panam Salud Publica. 2005;18(2):114-21.

40. Wells J, Bowers L. How prevalent is violence towards nurses working in general hospitals in the UK? J Adv Nurs. 2002;39(3):230-40.

41. İlhan MN, Ozkan S, Kurtcebe Z, Aksakal FN. Gazi Üniversitesi Tıp Fakültesi Hastanesinde çalışan araştırma görevlileri ve intörn doktorlarda şiddete maruziyet ve şiddetle ilişkili etmenler. Toplum Hekimliği Bülteni. 2009;28:15-23.

42. Aydın M. Isparta-Burdur sağlık çalıșanlarına yönelik șiddet ve şiddet algısı. Türk Tabipleri Birliği, Isparta- Burdur Tabip Odası Başkanlığı; 2008.

43. Öztunç G. An examination of verbal and physical abuse incidents that nurses encounter in their work, in various hospitals in Adana. Journal of Nursing College of Cumhuriyet University. 2001;5(1):1-9.

44. Ergun FS and Karadakovan A. Violence towards nursing staff in emergency departments in one Turkish city. Int Nurs Rev. 2005;52:15460.

45. Barrett S. Protecting against workplace. Public Manag. 1997;79:9-12.

46. Gates DM. Workplace violence. AAOHN J. 1995;43:536-43.

47. Aydın B, Kartal M, Midik O, Büyükakkus A. Violence against general practioners in Turkey. J Interpers Violence. 2009;24(12):1980-94.

48. Erkol H, Gokdoğan MR, Erkol Z, Boz B. Aggression and violence towards health care providers-a problem in Turkey? J Forensic Leg Med. 2007; 14:423-8

49. Aslan Ö, Lofçalı A, Uğur Ş, Tuğlu A. Hemşirelerin acil serviste şiddet içeren olgu senaryolarına yaklaşımları. Gülhane Tıp Dergisi. 2005;47(1):18-23. 